\title{
Do UN Interventions Cause Peace? Using Matching to Improve Causal Inference*
}

\author{
Michael J. Gilligan ${ }^{1}$ and Ernest J. Sergenti ${ }^{2}$ \\ ${ }^{1}$ Nem York University, USA \\ ${ }^{2}$ New York University and Harvard University, USA
}

\begin{abstract}
Previous statistical studies of the effects of UN peacekeeping have generally suggested that UN interventions have a positive effect on building a sustainable peace after civil war. Recent methodological developments have questioned this result because the cases in which the United Nations intervened were quite different from those in which they did not. Therefore the estimated causal effect may be due to the assumptions of the model that the researchers chose rather than to peacekeeping itself. The root of the problem is that $\mathrm{UN}$ missions are not randomly assigned. We argue that standard approaches for dealing with this problem (Heckman regression and instrumental variables) are invalid and impracticable in the context of UN peacekeeping and would lead to estimates of the effects of $\mathrm{UN}$ operations that are largely a result of the assumptions of the statistical model rather than the data. We correct for the effects of nonrandom assignment with matching techniques on a sample of UN interventions in post-Cold-War conflicts and find that UN interventions are indeed effective in the sample of post-civil-conflict interventions, but that UN interventions while civil wars are still ongoing have no causal effect.
\end{abstract}

* We are indebted to Jas Sekhon for his sage advice on GenMatch and matching generally. Neal Beck and Gary King graciously provided expert methodological advice. We thank Han Doruson, Ismene Gizelis, Kristian Gleditsch, Birger Heldt, Macartan Humphreys, and the other participants in the Peacekeeping Working Group, which is generously funded by the Folke Bernadotte Academy, Sweden. We also thank Bill Durch, Miles Kahler, David Lake, Jodi Nelson, Irfan Noorudin, Philip Roeder, Barbara Walter, and the other participants at the UCSD Conference on Peacebuilding in Fragile States. Bruce Bueno de Mesquita, Page Fortna, and Eric Voeten generously offered extensive comments. Finally we thank the two anonymous QJPS reviewers. All errors remain our responsibility.

Supplementary Material available from:

http://doi.dx.org/10.1561/100.00007051_supp

MS submitted 31 October 2007; final version received 22 April 2008

ISSN 1554-0626; DOI 10.1561/100.00007051

(C) 2008 M. J. Gilligan and E. J. Sergenti 
Do UN interventions cause peace? Establishing causality as opposed to mere correlation is one of the most difficult endeavors a social scientist can undertake. ${ }^{1}$ Nowhere within the field of international relations is that endeavor more pressing than in evaluating the effectiveness of UN operations. Previous statistical studies have generally suggested that UN interventions have a positive effect on the likelihood of peace after civil war (Doyle and Sambanis 2000, Fortna 2004, 2008). However, recent methodological developments have cast something of a shadow over these results (King and Zeng, 2007). The problem is that the cases in which the United Nations intervened were quite different from those in which they did not, and therefore estimates of the effects of the UN operations were largely extrapolations from the available data. As a result the findings were primarily driven by the researchers' assumptions about the proper statistical model rather than the data, and therefore we cannot be sure if the estimated causal effect of peacekeeping is due to peacekeeping itself or to the functional form of the estimation technique that the researchers chose.

As we discuss below this extreme-counterfactual problem arises because of the nonrandom assignment of $\mathrm{UN}$ peacekeeping missions to civil conflict. If we fail to control for this problem we cannot be sure if the estimated causal effect of peacekeeping is due to peacekeeping itself or to other factors that are common among cases that received peacekeeping operations and not common among cases that did not. Researchers often address the problem of nonrandom assignment by employing a Heckman selection model. The researcher creates a model of the treatment-assignment (selection) process, uses that model to generate predictions of counterfactuals and then compares the factual cases to these predicted counterfactuals. When using such a technique, the researcher implicitly assumes that he/she can account for nonrandom assignment by means of a single, estimable selection equation that accurately predicts the presence of the nonrandomly assigned treatment - in this case a UN intervention. Furthermore in order to operationalize such a procedure, the researcher must find an instrument - a variable that influences whether the United Nations is present in a given country but does not influence the chances of peace in that country. Both of these requirements raise troubling questions about the validity of estimating the causal effect of $\mathrm{UN}$ intervention with a Heckman model.

With regard to the functional form of the underlying selection equation, it is not clear that one equation can accurately account for the presence of the United Nations. Even if we could develop a model of the UN Security Council selection process, some cases are never considered by the Security Council for any number of reasons. Thus, in order to model accurately the UN's selection of intervention the researcher must model which cases are brought to the UN's attention in the first place - yet another selection process. Combining these processes into one equation to be used as an initial selection equation in the Heckman procedure would severely complicate the analysis and make the predictions of such a model highly dependent on the functional form of the equations

1 A fuller discussion of the different approaches to causality is beyond the scope of this paper. For a complete discussion of the various approaches to causality see Pearl (2001). We adopt the Rubin causal model (Rubin 1979, Rosenbaum and Rubin 1984). 
chosen. With regard to the need for an instrument, we have good theoretical reasons for thinking that one does not exist. Any factor that affects how long a war or its subsequent peace will last should also be taken into account by the UN Security Council when it is deciding whether or not to allocate a mission.

For these reasons, instead of using a Heckman model we correct for the effects of nonrandom assignment by using a method advanced by Rubin (1979), Rosenbaum and Rubin (1984), and Ho et al. (2007). We find observations within our control group (those that did not receive UN peacekeeping missions) that match as closely as possible our treated cases (those that did receive UN peacekeeping missions) before analyzing the subset of data with a Cox proportional hazard model. We make inferences about the causal effect of UN intervention based on a comparison of these most-similar cases. The idea is to compare cases where all other causal variables are as similar as possible so that any difference between the cases can be attributed to the treatment. In this way matching comports with tried-and-true techniques of comparative political research. Matching effectively employs Mill's method of difference and Przeworski and Teune (1970)'s most similar systems design. The innovation is that matching uses a relatively large $n$ compared to most comparative case study research and it utilizes a rigorous set of criteria by which to judge if cases are sufficiently similar.

Matching has the further virtue that the analysis is completely transparent (we list the cases we compare in Tables 2 and 5) and inferences are based entirely on the data. None of the results flow from arcane functional form assumptions or implausible arguments about valid instruments. Matching makes inferences about the effects of UN intervention from the types of cases where it actually intervenes and not from extrapolations based on assumptions about what would have occurred in cases that have never been observed.

Although our method cannot control for unobserved variables that might affect both war outcomes and UN intervention the way the Heckman approach can (assuming that the researcher has a valid instrument and knows the proper functional form of the data generating process), our own view is that we have sound theoretical reasons for thinking that a valid instrument does not exist and furthermore that we, as political scientists, have a much better grasp of potential confounding covariates (variables that are correlated with both war outcomes and UN intervention) on which to match than we do of the precise functional form of the relationship between civil war, UN intervention and these confounding covariates. These considerations recommend a matching rather than a Heckman approach.

In our analysis we divide our sample into two sub-samples: a post-conflict sample and an in-war sample. In our post-conflict sample, the dependent variable is the duration of the peace period following a civil conflict and in our in-war sample the dependent variable is war duration. We limit our analysis to the post-Cold War period because the end of the Cold War represents a major structural break in the data generating processes for war and peace durations and for UN interventions. We establish the causal efficacy of UN intervention by employing techniques that match treated observations with similar control cases. In that way we are able to establish that the effect on peace (if any) was truly due to the presence of an operation and not to other extraneous factors because we 
only compare cases where those extraneous factors are quite similar, and therefore could not be an explanation for the observed variation.

Our results suggest that failing to correct for the effects of the nonrandom assignment of the treatment leads to biased causal inferences about the effects of UN intervention in both post-civil-conflict settings and ongoing civil wars. In post-conflict settings UN intervention appears to significantly reduce the hazard of war occurrence and failing to control for the effects of nonrandom assignment would lead one to underestimate that effect. In in-war settings UN interventions appear to have no effect on the likelihood that the war will end and failing to correct for the effects of nonrandom assignment would lead one to conclude that $\mathrm{UN}$ intervention was quite efficacious at ending wars.

\section{PREVIOUS EVALUATIONS OF UN INTERVENTIONS}

The literature on peacekeeping is very large so we cannot review it in its entirety. Instead we discuss some of the main findings relying on a few key studies. We begin by discussing the predominant theoretical account of the causal efficacy of peacekeeping, focusing on the potential role that peacekeepers play in mitigating combatants' commitment problems. We then turn to a discussion of previous efforts to establish the causal efficacy of UN peacekeeping empirically.

At least since Fearon (1995) the two predominant explanations within the rational choice framework for why wars occur are commitment problems and incomplete information. ${ }^{2}$ Both explanations have implications for the role that peacekeeping may play in helping end conflict. Arguably the prevailing theory for why peacekeeping shortens wars and prolongs peace is that it helps warring factions overcome commitment problems. Civil wars, the theory goes, occur in societies where peace agreements are not self-enforcing. As a result the warring parties forgo Pareto efficient solutions to the war because they fear the opportunistic behavior of the other side. ${ }^{3}$ Peacekeeping missions can alleviate this situation by monitoring the behavior of the combatants. They can insure that the combatants are complying with the peace agreement and they can provide protection such that opportunistic behavior is less costly to its victims and less beneficial to the cheater. In theory peacekeepers fill the gap in the transitional period following a civil war until trust can be reestablished and self-enforcing domestic political institutions can take over. ${ }^{4}$

However, scholars, policy makers, and soldiers on the ground have questioned whether UN missions actually accomplish this task in practice. This view is common among scholars who conduct in-depth case studies of peacekeeping missions. Jett (2001), for

2 Powell (2006) has shown that Fearon's third explanation for war - indivisibility of the object under contention - is a special case of a commitment problem.

3 Fearon (2004) provides a model of such a process in the context of civil war and Powell (2004) offers a more general characterization of this problem.

4 See for example Walter (1997). Fortna (2008) (Chapter 4) describes four causal mechanism, three of which we interpret to be special cases of the commitment problem. The fourth is that peacekeepers can prevent accidental violations of peace agreements from reigniting the war. 
example, relying on a comparison of the cases of Angola and Mozambique, claims that too often the situations in which the United Nations is asked to operate are too complex, missions are underfunded and peacekeepers are hamstrung by overly bureaucratized procedures. This became a common view starting in the mid-1990s following the inaction of UN peacekeepers during the Rwandan genocide and the failure of the UN mission in Somalia. $^{5}$

Furthermore Luttwak (1999) argues that peacekeeping interventions often fail to achieve lasting peace:

[Peacekeeping] perversely, can systematically prevent the transformation of war into peace. The Dayton accords are typical of the genre: they have condemned Bosnia to remain divided into three rival armed camps, with combat suspended momentarily but a state of hostility prolonged indefinitely. Since no side is threatened by defeat and loss, none has a sufficient incentive to negotiate a lasting settlement; because no path to peace is even visible, the dominant priority is to prepare for future war rather than to reconstruct devastated economies and ravaged societies. Uninterrupted war would certainly have caused further suffering and led to an unjust outcome from one perspective or another, but it would also have led to a more stable situation that would have let the postwar era truly begin. Peace takes hold only when war is truly over.

Smith and Stam (2003) and Werner and Yuen (2005) make a similar argument more formally regarding the role of peacekeeping within the context of international conflict and the latter paper provides quantitative evidence for the claim. Stepping off from the incomplete information explanation for war these papers argue that war is an updating process through which combatants learn their opponents' true military strength. Only once this updating has occurred to a sufficient degree is a lasting peace possible. According to this argument peacekeeping hinders long term peace because it attempts to end the conflict before this necessary updating has occurred.

We are left with a plausible theoretical story about how peacekeeping may cause peace by mitigating combatants' commitment problems but with some questions raised as to whether peacekeeping actually fulfills that role in practice. We are also faced with rival theoretical accounts which claim that peacekeeping may give combatants an incentive to bargain intransigently and may impair their ability to update sufficiently on the military strength of their rivals - a necessary condition for lasting peace in an incomplete information model of war. Ultimately, whether peacekeeping actually fulfills its goals is an empirical question that must be answered with systematic analysis. It is to existing quantitative evaluations of that question that we now turn. We divide that literature into two categories - those that evaluate UN decisions to deploy missions and those that evaluate the performance of missions once deployed.

5 See, for example, Jones (2001) and Dallaire (2003) on Rwanda and Clarke and Herbst (1997), and Howe (1995) on Somalia. 
Fortna (2008) provides a thorough review of studies in the first category. We highlight three broad findings in the literature. First, there is fairly strong evidence, using a variety of measures of power, that the United Nations avoids sending missions to powerful countries (Gilligan and Stedman 2003, Fortna 2004, 2008, Mullenbach 2005). ${ }^{6}$ Second, there is some mixed evidence on the humanitarian impetus for UN missions. Gilligan and Stedman (2003) using duration analysis find strong consistent evidence that UN missions are more likely to be sent to wars the higher the number of casualties, and Mullenbach (2005) finds some weak evidence that the United Nations sends missions to the neediest cases. Fortna $(2004,2008)$, by contrast, finds no evidence for the proposition. ${ }^{7}$ Third, all studies find consistent evidence of regional bias in allocation of UN missions. ${ }^{8}$ These findings imply that $\mathrm{UN}$ missions are not randomly assigned and thus have an important implication for studies in the second category. These papers indicate that the cases in which the UN intervenes have clearly identifiable differences from cases where the United Nations does not intervene. As such we must worry about the effects of nonrandom assignment when making causal inferences about UN interventions.

Turning to the literature in the second category, which addresses the effectiveness of UN interventions, Doyle and Sambanis $(2000,2006)$ judge a mission a success if three criteria are met: (a) the war ends and does not resume for some specified period of time (b) residual violence does not resume within the same period of time and (c) there is some democratization within that time period. They find that, for the most part, UN operations are positively correlated with their measures of peace building success. Another important contribution to the evaluation of the effectiveness of UN peacekeeping is provided by Fortna (2004). She finds that UN missions prolong cease fires. Finally, although not exclusively a study of UN intervention, Hartzell et al. (2001) find that peace agreements last longer if there is a third-party intervention and in some of their sample the United Nations plays that role.

Another contribution of this paper, in addition to its correction of the nonrandom assignment problem is its treatment of ongoing wars. Fortna $(2004,2008)$ 's model is by design a model of post-conflict settings and as such does not address the effect of UN intervention while a war was still ongoing. Doyle and Sambanis (2000) examined seven cases of ongoing conflicts in their analysis; however they pooled them with civil wars that had ended. The data generating process of ongoing wars is quite likely different from that for wars that have ended. Indeed the civil war literature implicitly recognizes that pooling is inappropriate by treating war onset differently from war duration. ${ }^{9}$ Therefore,

6 Gilligan and Stedman and Fortna use size of government army as a measure. Mullenbach uses dummy variables for great-power and regional-power status.

7 Mullenbach dichotomized his measures and included multiple measures of need in his specifications which may have weakened his results. In addition, both Mullenbach and Fortna use a dichotomous dependent variable raising the issue of right censoring.

8 This regional differential is consistent with De Jonge Oudratt (1996)'s claim that countries that the Permanent Five members of the Security Council consider to be most important are more likely to receive missions but more specific evidence for this proposition is mixed.

9 In the former category see Fearon and Laitin (2003), Fortna (2004), Collier and Hoeffler (2004), Miguel et al. (2004) and Hegre and Sambanis (2006) among others. In the latter category see 
we allow the data generating process of the duration of the post-conflict period to be different from that of war duration.

Finally any review of quantitative studies of peacekeeping would be remiss if it failed to mention a recent debate between King and Zeng (2007) and Doyle and Sambanis (2007) with comments by other scholars (Morrow 2007, Schrodt 2007). King and Zeng (2007) argue that Doyle and Sambanis (2000)'s results are model dependent meaning the estimated causal effect of UN intervention changes substantially with minor modifications to the specification. Model dependence arises when counterfactual inferences are made by comparing treated and control samples that are too disjoint. For example as shown in Figure 1 there are no cases of post-conflict settings where the United Nations intervened and in which the previous war had log cumulative battle deaths of less than roughly five whereas there are many cases where the United Nations failed to intervene in that category. Thus predictions about what would have happened had the United Nations intervened following a conflict with relatively low casualties are extrapolations from the data. With no data on which to base such inferences causal claims are based on modeling assumptions rather than the data. ${ }^{10}$

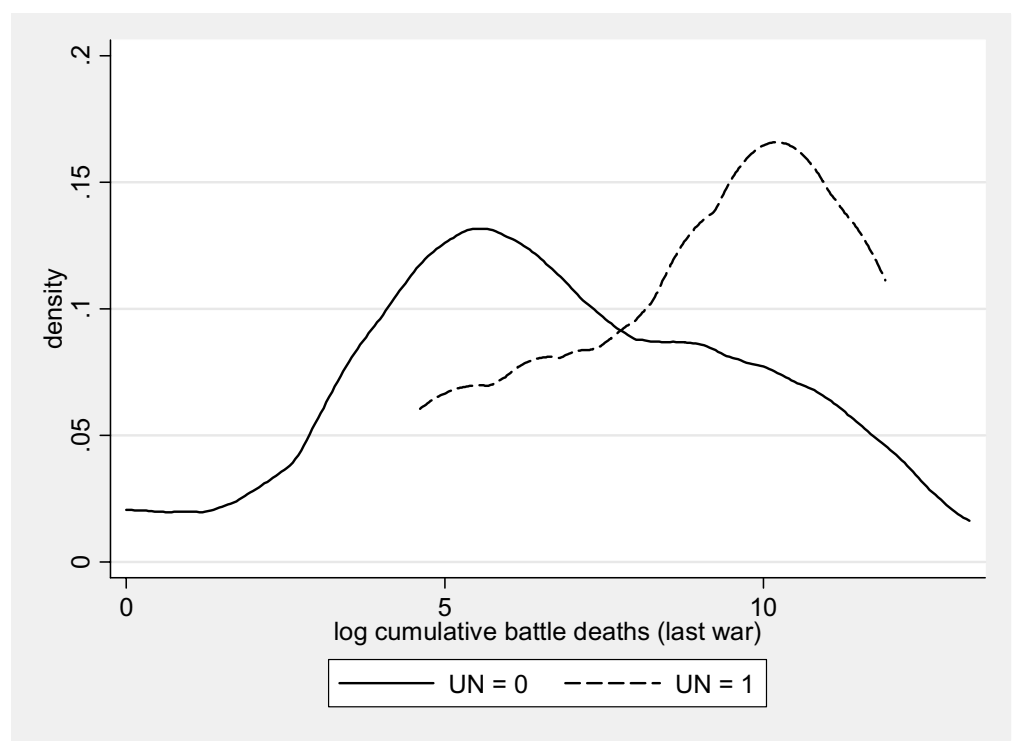

Figure 1. Kernel densities of $\log$ cumulative battle deaths in cases where the UN intervened $(\mathrm{UN}=1)$ and where it $\operatorname{did} \operatorname{not}(\mathrm{UN}=0)$.

Balch-Lindsay and Enterline (2000), Regan (2002), Fearon (2004), and Hegre (2004) among others. Elbadawi and Sambanis (2002) combine both approaches.

10 Doyle and Sambanis (2007) respond that they completed many robustness checks of their results and they dispute the method that King and Zeng (2007) recommend for testing for model dependence (the convex hull). 
We do not wish to rehash a debate that has already occurred elsewhere, since doing so would detract from our main substantive point (estimating the causal effect of UN peacekeeping) and our main methodological point (matching is a superior method to Heckman regression in establishing that causal effect in this case). We would point out, though, that the matching techniques we use corrects the extreme counterfactual and model dependence problem by insuring that the treated and the control groups are similar. As such King and Zeng (2007)'s critique of Doyle and Sambanis (2000) does not apply to the results in this paper.

\section{METHOD}

In evaluating the effect of UN missions in prolonging periods of peace or shortening periods of war it is useful to make an analogy to a laboratory experiment. In a laboratory the researcher is careful that the treatment he/she wishes to study is randomly assigned. In that way he/she can ensure that any difference in the outcome between the treated and untreated cases is due to the treatment and not some other different characteristics of the treated and the control groups. By virtue of randomizing the treatment, any such characteristics will not be correlated with whether the case received the treatment. By analogy we can think of UN intervention as the treatment. The duration of peace or war is the affected outcome. Unfortunately the treatment in this case is not randomly assigned. As such the researcher must be careful to make sure that any differences between the treated and control groups are in fact due to the treatment and not to some other characteristic that was common to the treated group but not the control group. For example, if, as shown in Figure 1, the post-conflict periods in which the UN intervenes are characterized by higher levels of cumulative battle deaths from the previous war and higher levels of cumulative battle deaths are associated with shorter periods of peace, then not controlling for the confounding influence of cumulative battle deaths biases the estimated causal effect of UN intervention.

The prevailing methodology to address these problems is to add a variable to a parametric estimator (ordinary least squares regression, probit, Heckman regression etc.) to control for that variable's confounding influence. But, as King and Zeng $(2006,2007)$ and Ho et al. (2007) argue, if the distributions of the confounding factors do not overlap sufficiently - in our case, for example, the distribution of the log of the cumulative battle deaths is farther to the right for those cases in which the United Nations intervened than it was for the cases where the United Nations did not intervene - then the causal inferences are sensitive to the unverifiable specification assumptions of the parametric model.

To improve the reliability of one's causal inferences, Ho et al. (2007) recommend preprocessing one's data using matching techniques in which treated cases are matched with similar untreated cases. Matching creates a sample of the data in which the difference between the treated distribution and the non-treated distribution is reduced. When matching is perfect and the distributions match exactly a simple difference in means of the treated and the untreated is sufficient to obtain the causal effect of the treatment. But in most cases matching is not perfect. In order to adjust for any remaining imbalance 
(and in our case to account for right-censoring) one should then use the same parametric model one would have applied to the full data set on the matched sub-sample. This, as Ho et al. (2007) describe, greatly reduces the role of functional form and specification assumptions of the parametric model, leading to more reliable causal inferences. This method is doubly robust: if matching is not complete but the parametric model is properly specified, or if the model is not properly specified but the matching is adequate, causal estimates will be consistent.

With each of our samples, we first identify the confounding factors. Confounding factors are those variables that (1) influence the dependent variable conditional on treatment, (2) are correlated with the treatment variable, and (3) are causally prior to treatment. Thus, for example, the growth rate of a country after a UN intervention is not a confounding factor even though it does influence the likelihood of peace ${ }^{11}$ and is correlated with a United Nations presence because it is not causally prior to a United Nations intervention and therefore the intervention may be creating the circumstances for higher growth. Including growth after a UN intervention in our analysis would lead to post-treatment bias, incorrectly controlling for the consequences of treatment, thus biasing the overall causal effect (Rosenbaum 2002, King and Zeng 2006, 2007). Therefore, when selecting our confounding factors, we must be careful that they meet all three requirements outlined above.

Once we have developed a list of confounding factors, we use one-to-one nearest neighbor matching with replacement to obtain matches from all of our control (nonintervention) cases for each of our treatment (intervention) cases. ${ }^{12}$ One-to-one nearest neighbor matching was preformed with GenMatch (Sekhon forthcoming), which uses a genetic search algorithm to determine the weight each confounding factor should receive in order to obtain optimal balance (Sekhon 2006b, Sekhon and Mebane 1998). Once we obtained matches, we analyzed the matched data with a Cox proportional hazards model, which corrects for any right censoring and remaining imbalance. ${ }^{13}$ Last, we present results of the Cox regression on the full unmatched sample to compare the causal effects estimated by the different procedures.

By necessity we estimate the average treatment effect on the treated (ATT). That is, we answer the question: how well did the United Nations do in the range of cases where it actually intervened and, if the United Nations were to intervene in a similar case, how well would we expect it to perform? We cannot tell how well the United Nations would have done had it intervened in a type of situation where it has never intervened (typically called the average treatment effect on the control or ATC). We do not have treated cases to match to all of our control cases and so we cannot answer that question. Like drugs and surgical procedures, United Nations interventions are designed for certain cases and not for others. For example, it is rare that the United Nations intervenes during a coup

1 See Collier and Hoeffler (1998, 2004) and Miguel et al. (2004).

12 We also used two-to-one matching. See below.

3 We also ran the same specification with different parametric models (exponential, Weibull, and lognormal) and the results were substantively the same. We prefer the Cox procedure because it is semi-parametric and therefore less dependent on any particular parametric assumption. 
presumably because they are typically over too quickly for the international community to put a mission in place. United Nations missions also tend not to be found in large countries. Thus, asking how well the United Nations would do if it were to intervene during a coup in a large country is not realistic because the United Nations does not intervene in such cases and so we have no data from which to make such inferences. We estimate how well the United Nations performs in the type of cases where it actually intervenes.

\section{THE EFFECT OF UN INTERVENTION IN PROLONGING PEACE}

\section{Sample Definition}

We begin with an analysis of the post-conflict sample. A fuller description of the data is available in the appendix. We adopt a country-level unit of analysis and our dependent variable is the number of months a given country was at peace following a civil conflict according to Gleditsch et al. (2002). We limit our attention to the post-Cold War period and our durations are right-censored at December 2003. Our treatment variable, a UN intervention in a country during a particular month, is a dichotomous variable equal to 1 if the United Nations was present at any point during the period of peace, and 0 otherwise. $^{14}$

\section{Confounding Factors}

Our confounding factors and reasons for including them are as follows:

Log (Cumulative Battle Deaths) from Last War. Battle deaths is a confounding factor because it is negatively correlated with the duration of the subsequent peace (Fortna 2004) and positively correlated with the probability that the UN intervenes (Gilligan and Stedman 2003). Indeed the before-matching balance statistics in Table 1 show that the cumulative battle deaths from the previous war of the treated group are significantly greater than those of the control group, and the Kolmogorov-Smirnov $(\mathrm{K}-\mathrm{S})$ test indicates that the two distributions are very different with a $p$-value of effectively zero. The battle death data come from Lacina and Gleditsch (2005).

Duration of Last War. The duration of the previous war is positively correlated with the duration of the subsequent peace (Hartzell et al. 2001, Fortna 2004) and has been shown to be positively correlated with the probability that the UN intervenes (Gilligan and Stedman 2003). The before-matching balance statistics in Table 1

14 We recognize the shortcoming of using a dichotomous measure of the treatment. UN missions come in many different sizes with different mandates. Unfortunately, we simply do not have enough cases of UN intervention to take these nuances into account reliably. The number of UN interventions in our sample (19 and 16 for the post-conflict and in-war samples, respectively) is already small. Dividing UN interventions into more fine-grained categories would reduce our sample size for each type of treatment even further and make reliable inference impossible. 


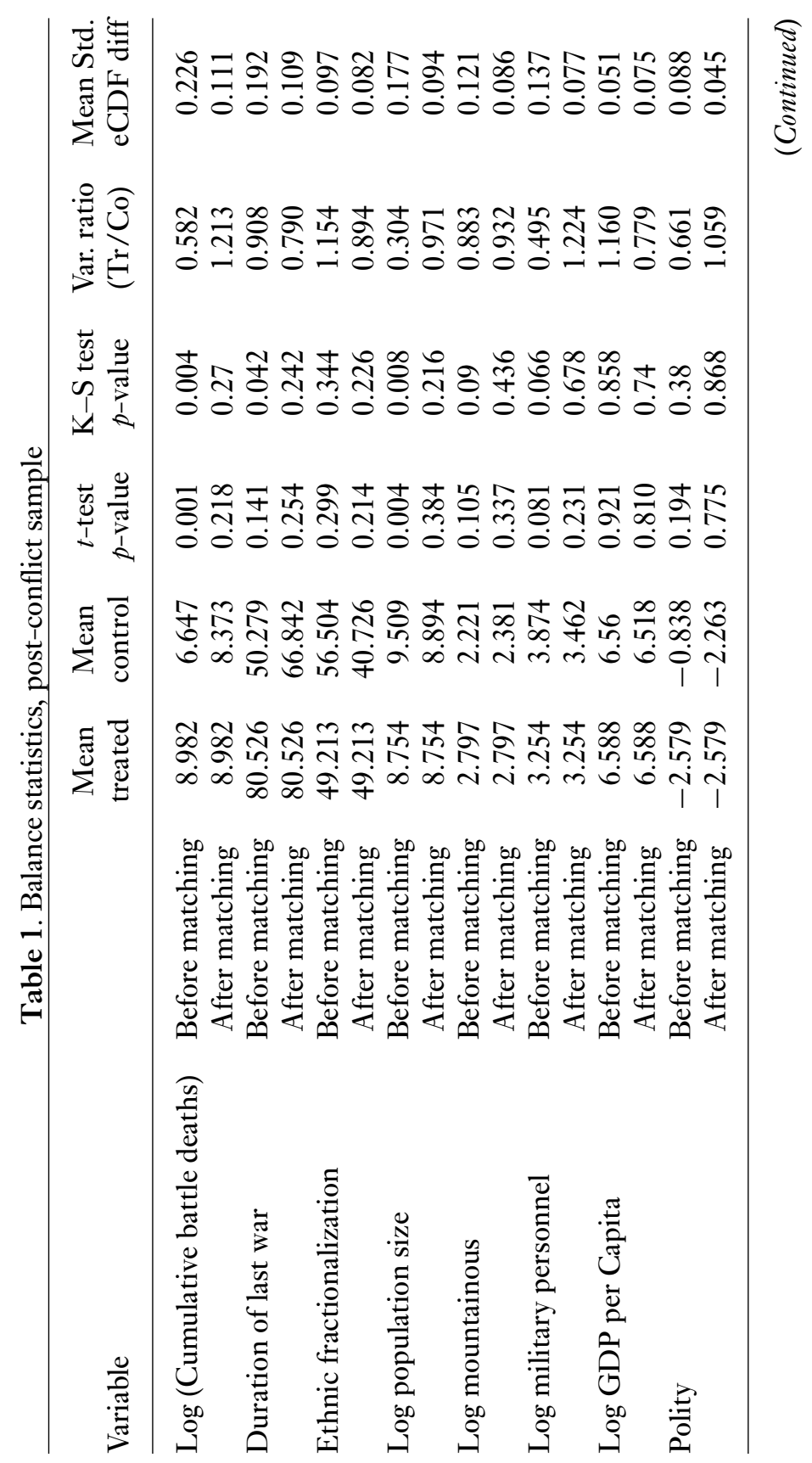




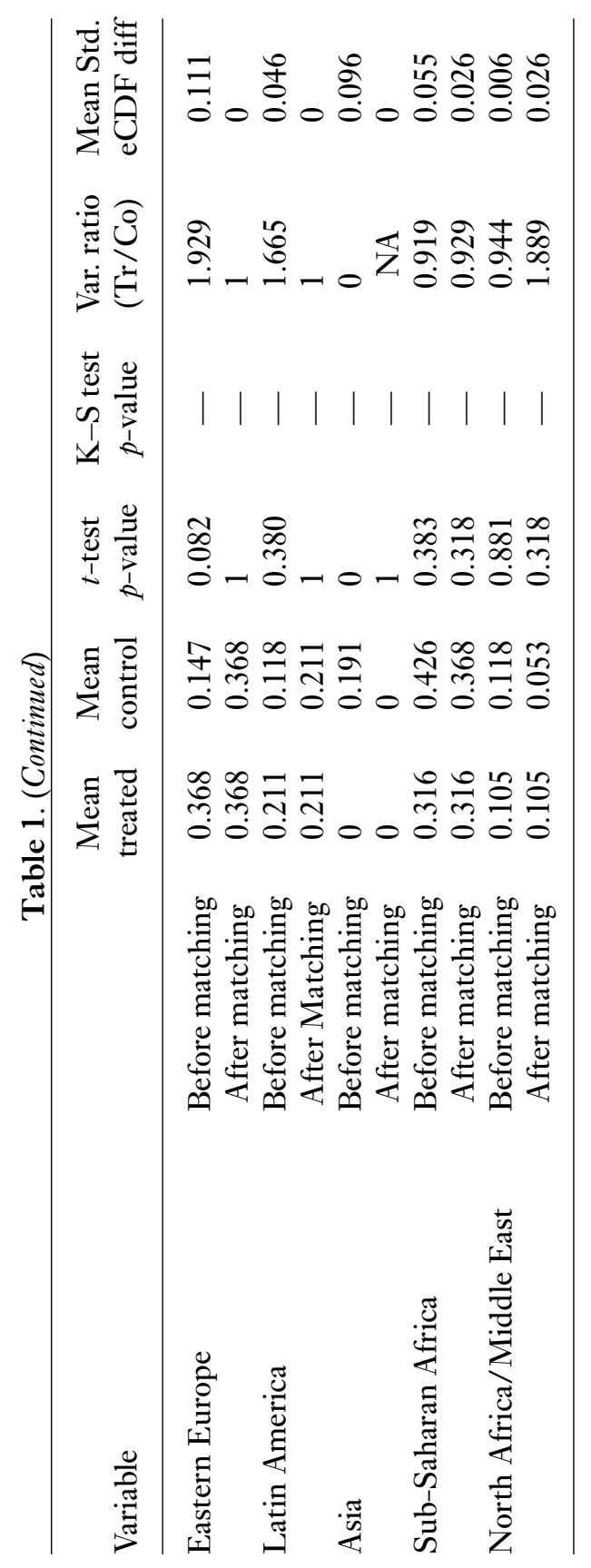


corroborate this finding - the United Nations tends to become involved following wars of longer duration. The $\mathrm{K}-\mathrm{S}$ test indicates that the two distributions are indeed significantly different.

Ethnic Fractionalization. Some authors have argued that ethnic fractionalization affects civil war onset and therefore would be negatively correlated with the duration of the peace period, although this finding is not robust (Fearon and Laitin (2003) which is the source of our ethnicity measure). Mullenbach (2005) offers some mixed evidence that the United Nations is more likely to intervene in ethnic conflicts. Our before-matching balance statistics in Table 1 indicate that there is no difference between the treated and control groups on this dimension. Still we include the variable as a confounding covariate to avoid any omitted variable bias.

Log (Population Size). Collier and Hoeffler $(1998,2004)$ found that countries with large populations are more prone to civil war. As shown in Table 1 populations of countries in which the United Nations intervened were smaller than the countries in which they did not intervene and both the $t$-test on the difference of means and the $\mathrm{K}-\mathrm{S}$ test on the difference of the distributions indicates that this difference is highly significant. Our population data come from the World Bank World Development Indicators, 2005.

$\log$ (Mountainous). Fearon and Laitin (2003) (our source for this measure) found that countries with more mountainous terrain are more likely to have outbreaks of civil war. Therefore, mountainous terrain is negatively correlated with the duration of the peace period. As shown in Table 1 the United Nations also appears to intervene in more mountainous countries. The $\mathrm{K}-\mathrm{S}$ test indicates that the distributions of treated and control groups are statistically different. Fortna (2008) also found that the United Nations is more likely to intervene in countries with mountainous terrain.

Log (Military Personnel). Gilligan and Stedman (2003) and Fortna (2008) found that the size of a country's government army was negatively correlated with the likelihood that the United Nations would intervene in that country. Furthermore periods of peace should be longer in such states because large government armies should deter would-be rebels. We were unable to establish this hypothesized correlation, however, probably because the variable is endogenous to the threat of civil war governments have large armies because their countries are more civil-war prone. Therefore, we include the variable because we have theoretical reasons for doing so and to err on the side of caution in taking account of possible confounding factors. Our measure of military personnel comes from David et al. (1972) and Singer (1987).

Democracy before Last War. Hartzell et al. (2001) suggest that democracies are less prone to civil war, so democracy should be positively correlated with duration of peace. Andersson (2000) suggests that the United Nations is more likely to intervene in democracies. Using the Polity 2 measure from the last month before the civil war started, our before-matching balance statistics in Table 1 indicate that the treated and control groups may be different, albeit in the opposite direction of Andersson's 
hypothesis - countries in which the United Nations intervened appear to be less democratic than those in which the United Nations did not intervene.

Regional Controls. Gilligan and Stedman (2003), Fortna (2004, 2008), and Mullenbach (2005) found that the probability of a UN mission being allocated varied by region. Survival-time analysis (not shown) also indicated that duration of peace varied by region. Our regional categories are Latin America, Asia, North Africa/Middle East, Sub-Saharan Africa, and Eastern Europe. ${ }^{15}$

\section{Results}

We now turn to the creation of our matched sub-sample. We generated matched observations using one-to-one matching with replacement. ${ }^{16}$ Table 1 presents before and after balance statistics and the matched cases are listed in Table 2. There are several methods for describing the balance of a sample (see Imai et al. (2006) and Sekhon (2006a)). In what follows, we look at three standard indicators of balance: the difference in means, the $p$-values from a $t$-test on the difference of means, and where possible, the $p$-values from a K-S test of similar distributions. We also include the ratio of the variances of the treated and control samples and the mean standardized empirical CDF difference. QQ plots are available in the appendix.

The balance statistics presented in Table 1 indicate that we have achieved excellent balance. The $p$-values on all $t$-tests and $\mathrm{K}-\mathrm{S}$ tests are above 0.2 . The mean empirical CDF difference improves in all cases except log GDP per capita and the North Africa/Middle East dummy variable, both of which were balanced before matching and continued to have excellent balance after matching.

As shown in Table 2, our matching procedure has produced matched pairs that are quite similar. ${ }^{17}$ Look for example at the matched pair Liberia and Guinea-Bissau. Both are West African countries that erupted in civil war in the 1990s. Both civil insurgent movements aimed to topple strongmen who had taken power in 1980 (Samuel Doe in Liberia and João Bernardo Vieira in Guinea-Bissau) (Adebajo 2002, Massey 2006, Timeline: Guinea-Bissau 2008, Timeline: Liberia 2008). As the data in Table 3 show neither country is mountainous and the two countries have very similar pre-war GDPs, sizes

15 In addition to the variables listed above we also matched on whether the rebels in the previous war were contraband funded, whether the last war was a sons-of-the-soil war and whether it was a coup or revolution (see the next section for a fuller explanation of the variables). These variables were taken from Fearon (2004). Including these variables did not change our substantive findings. We chose not to include those variables in the results we present here for two reasons. First, missing values for these measures reduced our sample size by about $10 \%$. Second, we had less faith in the applicability of these measures to our post-conflict sample. Fearon (2004), our source for the variables, used them to explain war duration. As such they were measures for specific wars and do not necessarily carry over into the the post-conflict period.

16 We also performed our analysis using two-to-one matching. The results of the subsequent analysis were not substantively modified.

17 Balance is a sample property. Matching does not guarantee that any two matched pairs are the same (or close to it) except for random error. This is not a feature peculiar to matching techniques; it is true even in randomized experiments. We highlight a few cases for illustrative purposes only. 
Table 2. Matched pairs, post-conflict sample

\begin{tabular}{ll}
\hline Treated, peace period start date & Control, peace period start date \\
\hline Haiti Jan 1992 & Panama Nov 1989 \\
Guatemala Jan 1996 & Paraguay Mar 1989 \\
El Salvador Jan 1992 & Peru Jan 2000 \\
Nicaragua Jan 1990 & Paraguay Mar 1989 \\
Croatia Jan 1994 & Azerbaijan Aug 1994 \\
Croatia Jan 1996 & Azerbaijan Aug 1994 \\
Serbia and Montenegro Jul 1999 & Serbia and Montenegro Jan 1992 \\
Bosnia and Herzegovina Jan 1996 & Azerbaijan Aug 1994 \\
Georgia Jan 1994 & Moldova Aug 1992 \\
Liberia Sep 1995 & Guinea-Bissau June 1999 \\
Sierra Leone Jan 2001 & Burundi Jan 1993 \\
Zaire Jan 2002 & Zaire Jan 1998 \\
Rwanda Jan 1995 & Burundi Jan 1993 \\
Mozambique Nov 1992 & Somalia Jan 1997 \\
Namibia Jan 1990 & Chad Jan 1989 \\
Morocco Jan 1990 & Iraq Jan 1997 \\
Lebanon Jan 1991 & Azerbaijan Aug 1994 \\
Tajikistan Jan 1997 & Azerbaijan Aug 1994 \\
Tajikistan Jan 1999 & Niger Jan 1998 \\
\hline
\end{tabular}

Table 3. Case studies of matched pairs: Liberia/Guinea-Bissau and El Salvador/Peru

\begin{tabular}{lccccc}
\hline Variable & Liberia & Guinea-Bissau & El Salvador & Peru & $\begin{array}{c}\text { Sample } \\
\text { St. Dev. }\end{array}$ \\
\hline $\begin{array}{l}\text { Log cumulative battle } \\
\quad 1 \text { deaths }\end{array}$ & 10.043 & 7.523 & 10.915 & 10.338 & 3.118 \\
$\begin{array}{l}\text { Duration of last war } \\
\text { Ethnic }\end{array}$ & 69 & 12 & 156 & 240 & 79.803 \\
$\quad$ fractionalization & 82.991 & 80.376 & 16.592 & 58.969 & 25.490 \\
$\begin{array}{l}\text { Log population } \\
\text { Log mountainous }\end{array}$ & 7.913 & 7.192 & 8.577 & 10.162 & 1.370 \\
$\quad$ terrain & 0.470 & 0 & 2.425 & 3.884 & 1.387 \\
$\begin{array}{l}\text { Log military personnel } \\
\text { Log GDP per capita }\end{array}$ & 1.609438 & 1.94591 & 3.892 & 4.745 & 1.635 \\
$\quad$ before war & 6.021 & 5.241 & 7.578 & 7.847 & 1.011 \\
Polity2 before war & -6 & 0 & -6 & 3 & 5.700 \\
\hline
\end{tabular}


of populations and government armies. Guinea-Bissau was somewhat less authoritarian according to Polity 2 and the civil war lasted longer in Liberia, but none of these differences are statistically significant. Indeed all variables are less than one standard deviation apart with the exception of the Polity 2 score, which has just a little over one standard error difference.

A second example of the correspondence between the matched pairs is the matching between El Salvador and Peru. Both conflicts involved a struggle between communist insurgencies and the state. Poverty is widely blamed as an underlying cause of both conflicts. Both began roughly in 1980 and ended in the early 1990s. The data in Table 3 show that there are no significant differences between the two countries on any of our covariates. In particular the countries have very similar pre-war GDPs, and causalities from the war. Peru is more mountainous, populous and ethnically diverse but none of these differences are significant. Peru was somewhat less authoritarian at the start of the war according to the Polity 2 score although not significantly so and even this difference must have waned as Alberto Fujimori the president of Peru adopted more authoritarian tendencies (McClintock 1998).

The traditional method for calculating the causal effect of a treatment is to take a difference in means. However, our dependent variable is the duration of a period of peace and many of our cases are right censored, so we employ a duration model instead to control for the right censoring and any remaining imbalance with the confounding factors. The top panel of Table 7 presents the causal effect of UN intervention estimated by a Cox regression on the unmatched and matched samples. The Cox regression results are presented in the relative hazard metric. In addition to the dummy variable for United Nations intervention (the treatment) we also included all of the confounding factors listed in Table 1 as controls in our Cox estimation, but we only present the coefficients for the treatment variable in Table $7 .^{18}$

According to the estimates from the Cox regression on the matched sample, a United Nations' presence results in the reduction of the hazard rate of war by over $85 \%$ or by a factor of 0.144 . Hence, for instance, if the monthly probability of returning to war without a UN intervention were $1 \%$, our results show that that same probability with a UN intervention would be only $0.144 \%$, a huge effect. Furthermore the comparable estimate from the unmatched sample is that $\mathrm{UN}$ intervention reduces the hazard rate of transition to war by a factor of 0.297 , which indicates that estimates of the effect of UN intervention, when they do not correct for the effects of nonrandom assignment of the $\mathrm{UN}$ intervention, are biased. They underestimate the effectiveness of UN intervention in prolonging post-conflict peace.

In summary, our results from the post-conflict sample clearly indicate UN intervention significantly reduces the proportional hazard of returning to war. Furthermore, our results show that it is crucial when evaluating the record of $\mathrm{UN}$ missions in post-civil-war settings to take into account the effects of nonrandom assignment of UN interventions.

18 The confounding variables are included in the Cox estimation only to control for any remaining imbalance. We do not present those coefficients because they are substantively meaningless since we have matched on those variables. 
Not correcting for this problem produced underestimates of the effectiveness of UN missions in post-conflict settings.

\section{THE EFFECT OF UN INTERVENTION ON SHORTENING WARS}

\section{Sample Definition}

Our dependent variable in this section is the duration of war. As before we focus on the post-Cold War period and our dependent variable is right censored in December 2003. One important feature of the in-war sample compared to the post-conflict sample is that the timing of UN interventions is more critical. With the post-conflict cases it was reasonable to ignore the differences in the timing of the UN interventions because most of them occurred in the first month of the peace period. With the in-war cases it is the exception that the United Nations is present from the start of the war. ${ }^{19}$ Hence, to properly examine the effect of the United Nations, we cannot use a time-invariant UN intervention variable as we did with the post-conflict sample. Doing so would substantially underestimate the effectiveness of the UN mission, because a war could have been going on for many years before the UN intervened, and then, after the UN intervened, stop after a few months. The relevant metric is instead "how long does the war last once the United Nations has intervened?" Regan (2002) also highlights this issue, which is why he argues for the use of a duration model with time-varying covariates. For the same reason, we estimate a time-varying covariates model on the unmatched data for our in-war sample.

When we turn to our matched sample, however, a time-varying-covariates approach causes concern about post-treatment bias. For example, after a UN intervention, the number of yearly battle deaths could go down, which might affect the outcome of the war. Controlling for this factor after the UN intervenes biases the estimated effect of the United Nations, but not controlling for it before the United Nations entered would fail to address the nonrandom assignment of the UN treatment. Our solution is to transform our time-varying data set by taking snapshots of the data for different durations of the war. In cases with a UN intervention we take a snapshot at the month that the UN intervened, freezing the time-varying variables at their values in that month and match on the variables at those values. Furthermore the cumulative duration of the war up until the point the snapshot was taken is one of our confounding covariates. For example, it would be inappropriate to compare the effect of a UN intervention in, say, the 40th month of a war, with a similar war in, say, its second month. Thus we need to take snapshots of each non-UN case at different durations of the war in order to match the treated UN cases appropriately. In other words we match on the duration of the war and on the level of the particular time-varying covariates at the time the UN intervened. We then examine the effect of the entire

19 This happened only in Rwanda and Tajikistan where a United Nations intervention was already in place for other reasons when civil war erupted. 
period from the time after the UN intervened, even if the United Nations left after a few years (as it did in Somalia, Angola, and Cambodia). The difference from the postconflict sample is that we only start to examine the in-war case once the United Nations has intervened, not before. Doing so gives us the correct counterfactual: how much longer would the country have remained in a state of war had the United Nations not intervened?

\section{Confounding Factors}

We now present the confounding variables on which we matched in our in-war sample and our reasons for doing so. ${ }^{20}$

Non-United Nations Third Party Interventions. Regan (2002) shows that international interventions increase the duration of war. Furthermore, our before-matching balance statistics, shown in Table 4, indicate that proportionally more of the treated group experienced a non-United Nations third party intervention than did the control group.

Pre-Observation War Duration. In the in-war sample the UN appears to intervene sooner, although the difference between the treated and control samples is not significant. Nonetheless we match on this variable to avoid omitted variable bias.

Log (Battle Deaths). As in the post-conflict sample high battle deaths may both reduce the hazard rate of peace and increase the likelihood that the UN intervenes. The before-matching statistics in Table 4 indicate that the average battle deaths of the treated group are higher than that of the control group, although not significantly. We match on this variable nonetheless to avoid omitted variable bias. Note that this is a time-varying measure for the ongoing war in contrast to the measure we used in the post-conflict sample.

Coup/Revolution. This is an indicator variable for whether the war was a coup or revolution. Fearon (2004), who is our source for these data, found that such wars are shorter in duration. We expected the United Nations to be less likely to intervene in these conflicts because they are shorter, however our before-matching statistics did not bear out this expectation. They indicate that it is unlikely that our treated and control groups are different along this dimension. We match on it to avoid omitted variable bias.

Sons-of-the-Soil. This is an indicator variable for whether the war was a sons-of-thesoil conflict defined as a "land conflict between a peripheral ethnic minority and state-supported migrants of a dominant ethnic group." This measure is from Fearon (2004) who found that such wars lasted longer than other types of wars. Our before-matching balance statistics indicate that those conflicts that receive a UN mission are significantly less likely to be sons-of-the-soil conflict than those conflicts that do not receive a $\mathrm{UN}$ mission.

20 Note, by design, before-matching balance statistics are for the generated time-variant UN interventions and snapshot control cases and not for the original time-varying data. 
Rebels Contraband Funded. This is an indicator variable for whether the rebel group in the war was financed by trade in contraband (drugs, diamonds, etc.). Such funding has been shown to increase the duration of the war by Fearon (2004) who is our source for these data. Our before-matching balance statistics do not give great cause for concern but probit estimates (not shown) indicated the United Nations was significantly more likely to intervene in conflicts where the rebels were contraband funded and so we include this variable as a possible confounding factor.

Ethnic Fractionalization. By some accounts ethnic fractionalization prolongs war. Furthermore, unlike in the post-conflict sample there is a strong indication from the $\mathrm{K}-\mathrm{S}$ test in Table 4 that those conflicts in the in-war sample that received a UN operation had lower levels of ethnic heterogeneity than those conflicts that did not.

Log (Population Size). Similar to the post-conflict sample this variable is positively correlated with the duration of war and negatively correlated with the likelihood of UN intervention. The $t$-test shows that the treated cases had significantly smaller populations than the untreated cases and the $\mathrm{K}-\mathrm{S}$ test indicates that the distributions are quite different.

Log (Mountainous). Following Fearon and Laitin (2003) wars may be prolonged in countries with more mountainous terrain and the cases in which the United Nations became involved were less mountainous on average as indicated by the before-matching balance statistics in Table 4 . The $\mathrm{K}-\mathrm{S}$ test reveals that the distributions of the mountainous variable were not very different in the treated and the control groups. We include it to avoid any omitted variable bias.

Log (Military Personnel). As in the post-conflict sample, UN interventions are less prevalent in countries with large armies and we have theoretical reasons for thinking that a large military is correlated with the likelihood that a war ends. The former point is corroborated by the before-matching balance statistics in Table 4. The average number of military personnel in those countries into which the UN intervened was significantly smaller than in countries where the United Nations did not intervene.

Regional Controls. The before-matching balance statistics in Table 4 indicate that the treated cases are significantly less likely to be in Asia and more likely to be in Eastern Europe than control cases are. Survival time analysis (not shown) also suggested that length of war varied by region. Our regional categories were Latin America, Asia, North Africa/Middle East, Sub-Saharan Africa, and Eastern Europe.

\section{Results}

We generated matched observations using one-to-one matching with replacement. As a robustness check we also used two-to-one matching and it did not change the balance statistics or the results appreciably. Table 4 presents balance statistics, which indicate that we have achieved good balance. The $p$-values on all $\mathrm{K}-\mathrm{S}$ statistics are well above 0.5 with the exception of $\log$ population size and $\log$ military personnel. Even in these two exceptions the $p$-values on the $\mathrm{K}-\mathrm{S}$ tests are respectable at 0.14 and 0.156 , respectively. 


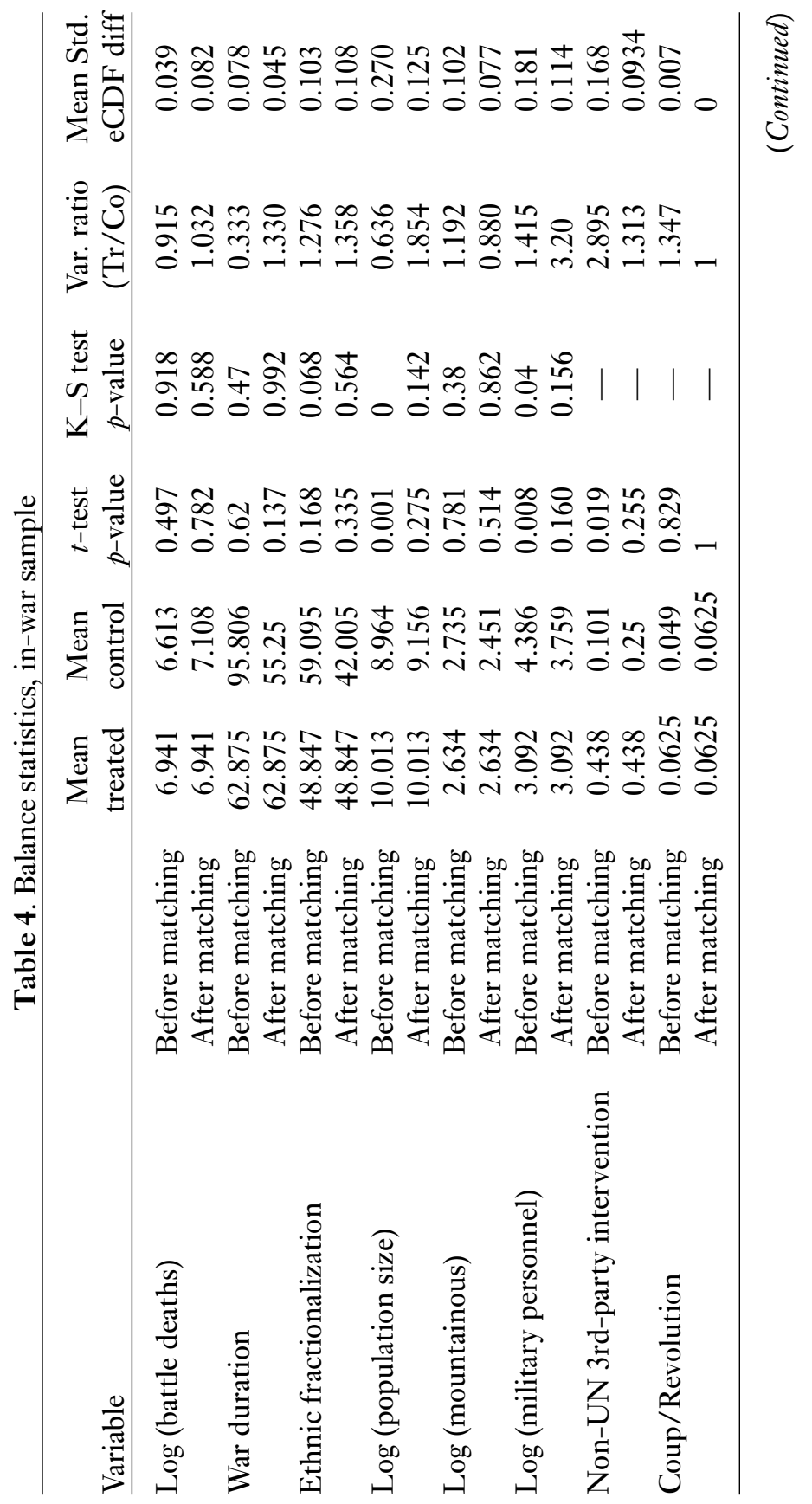




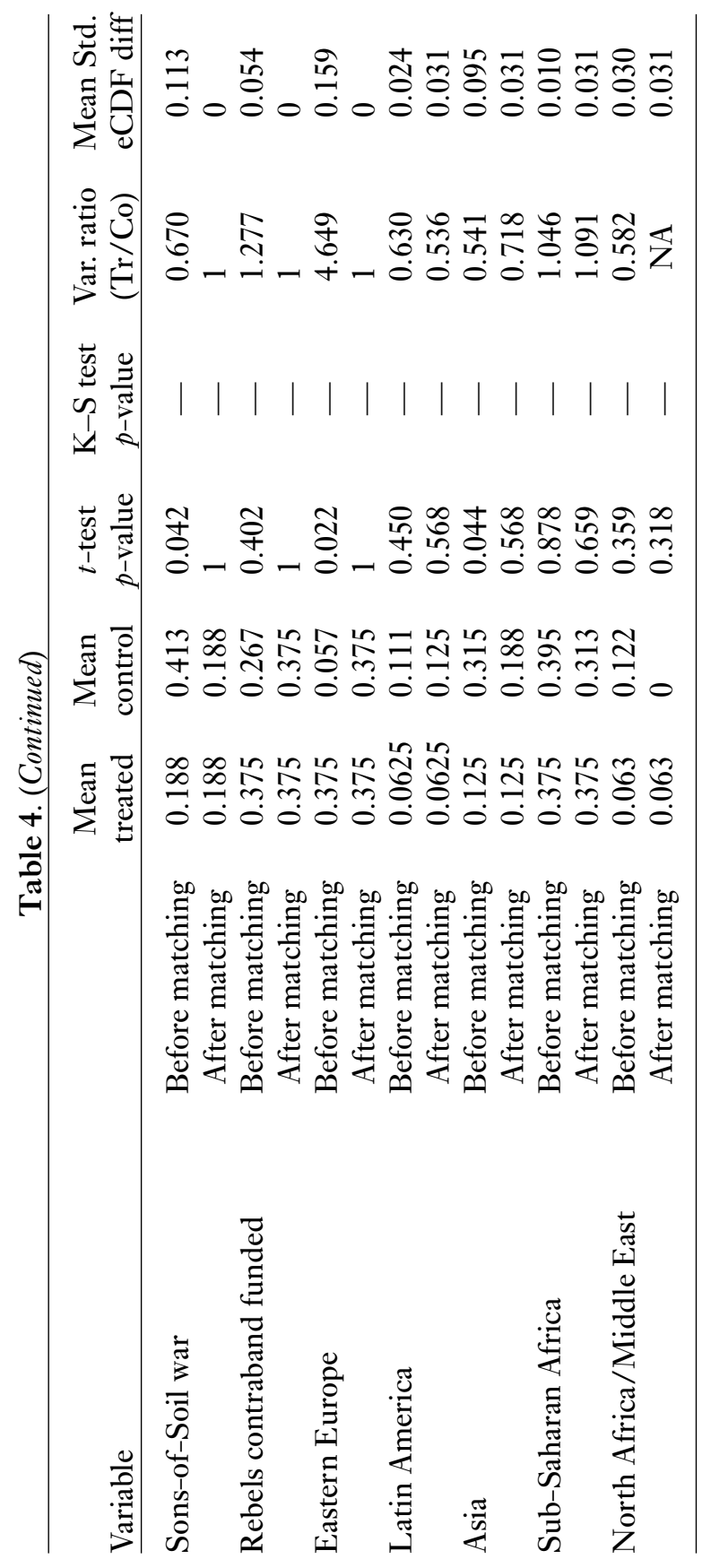


Table 5. Matched pairs, in-war sample

\begin{tabular}{ll}
\hline Treated, Month & Control, Month \\
\hline El Salvador Jul 1991 & Mozambique Jul 1988 \\
Croatia Feb 1992 & Moldova Apr 1994 \\
Croatia Jan 1995 & Moldova Mar 1992 \\
Bosnia and Herzegovina Jun 1992 & Azerbaijan Feb 1992 \\
Georgia Aug 1993 & Azerbaijan Dec 1992 \\
Liberia Sep 1993 & Senegal Oct 2000 \\
Sierra Leone Jul 1998 & Nicaragua Mar 1989 \\
Zaire Dec 1999 & Zaire Oct 1997 \\
Rwanda Jun 1993 & Rwanda Feb 2000 \\
Somalia Apr 1992 & Sri Lanka Oct 1994 \\
Angola Dec 1988 & Afghanistan Oct 1992 \\
Lebanon Jan 1988 & Burundi Oct 2002 \\
Tajikistan Dec 1994 & Azerbaijan Feb 1994 \\
Tajikistan Jan 1998 & Azerbaijan Jan 1992 \\
Cambodia Oct 1991 & Nicaragua Nov 1989 \\
Indonesia Oct 1999 & Myanmar (Burma) Apr 2000 \\
\hline
\end{tabular}

The matched pairs that resulted from our procedure, which are listed in Table 5, make good comparisons. ${ }^{21}$ For example, consider the matched pair between Croatia and Moldova. Both were ethnic conflicts in former communist countries that erupted as larger countries (Yugoslavia and the Soviet Union) broke apart. As shown in Table 6 the two countries are very similar on our confounding factors. Neither was a sons-ofsoil conflict or funded with contraband. Neither was a coup or a revolution or had a concurrent third-party intervention. Only log mountainous and log military personnel are more than one standard error from each other and in both cases the differences are not at all statistically significant.

Another example is the pairing of Indonesia and Burma. Both are southeast Asian countries racked with multiple ethnic conflicts. In Indonesia conflicts flared up in Aceh, Papua, and of course East Timor (Timeline: Indonesia 2008, Indonesia flashpoints: Aceh 2005, Indonesia flashpoints: Papua 2004, Timeline: East Timor 2008) while in Burma the Karen National Union, the Karenni National Progressive Party, and the Shan State Army are struggling for greater autonomy (Burma 'terrorising ethnic minorities' 2002, Burmese rebel leader in shot dead 2008). The confounding covariates are quite close in this comparison as well. Both countries are beset with sons-of-the soil conflicts funded by contraband and neither is a coup/revolution or experienced a concurrent international

21 As we pointed out above one should think of balance as a sample property rather than on a pair-bypair basis. These short case studies are offered for illustrative purposes. 
Table 6. Case studies of matched pairs: Croatia/Moldova and Indonesia/Burma

\begin{tabular}{lccccr}
\hline & Croatia & Moldova & Indonesia & Burma & $\begin{array}{r}\text { Sample } \\
\text { St. Dev. }\end{array}$ \\
\hline $\begin{array}{lcccc}\text { Concurrent international } \\
\quad \text { intervention }\end{array}$ & No & No & No & No & \\
$\begin{array}{l}\text { Coup or revolution } \\
\text { Sons of the soil }\end{array}$ & No & No & No & No & \\
Rebels contraband & No & No & Yes & Yes & \\
$\quad$ funded & & No & Yes & Yes & \\
Log battle deaths & 6.620 & 6.477 & 5.521 & 5.298 & 1.754 \\
Ethnic fractionalization & 33.422 & 55.157 & 76.406 & 47.550 & 26.606 \\
Log population & 8.441 & 8.378 & 12.226 & 10.771 & 1.367 \\
Log mountainous & 1.528065 & 0 & 2.442 & 3.600 & 1.243 \\
Log military personnel & 4.094345 & 2.197225 & 5.690 & 5.841 & 1.472 \\
\hline
\end{tabular}

intervention. Indonesia is somewhat more ethnically fractured and populous but not significantly so.

In the bottom half of Table 7, we present the estimated causal effect of UN interventions on the unmatched and matched samples. ${ }^{22}$ The importance of controlling for the effects of nonrandom assignment is clear. In estimates from the unmatched sample the Cox regression coefficient on the UN intervention variable suggests that the proportional hazard of a country transitioning out of war and into peace is almost three times greater in cases where the United Nations intervened. However, within the matched sample a United Nations presence has no effect. The hazard rate actually decreased by a factor of 0.72 , and the effect is not statistically significant. ${ }^{23}$ Thus failing to correct for the effects of nonrandom assignment of UN operations in the in-war sample would have lead us to overestimate the causal effect of the United Nations in shortening civil wars. While the substantive conclusion of our in-war sample is quite different from the one we reached in the post-conflict sample the methodological conclusion is the same - it is crucial that researchers control for the effects of nonrandom assignment when evaluating UN interventions. We might also point out that the different causal effects of UN operations in the post-conflict and in-war samples provides further evidence of the inappropriateness of pooling those two samples.

22 The size of the unmatched sample in the in-war analysis is much larger than that of the post-conflict sample because of the time-varying approach we adopt with the in-war samples.

23 As in the post-conflict sample these are multiple regression estimates. In addition to the UN treatment variable we included all of the confounding factors listed in Table 4. We do not report those coefficients because we have matched on those variables. 
Table 7. The causal effect of UN intervention: Cox proportional hazards estimates both samples pre- and post-matching

\begin{tabular}{cc}
\hline \multicolumn{2}{c}{ Post-Conflict Sample } \\
\hline $\begin{array}{c}\text { Unmatched, } n=87 \\
\text { Coefficient } \\
t \text {-stat. }\end{array}$ & $\begin{array}{c}\text { Matched, } n=38 \\
\text { Coefficient } \\
t \text {-stat. }\end{array}$ \\
\hline 0.297 & 0.144 \\
-2.04 & -2.18 \\
\multicolumn{2}{c}{ In-War Sample } \\
\hline Unmatched, $n=3999$ & Matched, $n=32$ \\
\hline 2.925 & 0.720 \\
2.01 & -0.44 \\
\hline
\end{tabular}

\section{DISCUSSION}

The central finding in this analysis is that UN peacekeeping missions have a strong significant effect in lengthening post-war periods of peace but have no significant effect in shortening wars and that both findings would have been missed without taking into account the effects of nonrandom assignment of the UN treatment. Not taking into account nonrandom assignment would have lead us to underestimate the effect of UN interventions in post-war peace settings and overestimate the effect of UN interventions in-war settings. These findings make a strong case that the effect of UN missions are quite different in peace and war situations and that those two subsamples should not be pooled. We would like to highlight the substantive significance of these findings. Claims based on quantitative evidence that UN peacekeeping is effective have come under a convincing methodological attack. The significance of our findings is that, using precisely the techniques that the critics have said should be used, we have been able to show that in fact UN peacekeeping is effective at least in post-conflict settings.

Our results raise at least two new interesting questions. First, why are UN peacekeepers good at addressing commitment problems after wars have ended but not while they are ongoing? Luttwak (1999), in the quote above, provides one potential explanation - UN interventions may actually lengthen some ongoing wars rendering the effect over the whole sample insignificant. If the UN intervenes after the war's end the bargaining problem of how to distribute post-war power and resources has effectively been solved by the time the United Nations enters. When the United Nations enters before the war's end these distributional issues have yet to be settled. According to this 
argument the entry of the United Nations alters the bargaining game. Once they are under the protective umbrella of a United Nations peacekeeping force the militarily weaker faction(s) have an incentive to be more demanding at the negotiating table. Having reduced the probability of an outright military defeat the UN mission has effectively increased the value of the militarily weaker side's disagreement point. Protected by the United Nations the warring factions are no longer faced with military defeat if they do not reach an agreement and therefore they may have more incentive to drag out negotiations. ${ }^{24}$

This argument does not entirely satisfy however. Bargaining is still costly even under the protection of the blue helmets. The argument made above suggests that bargaining strength may shift away from the militarily stronger factions toward weaker factions but that by itself cannot explain the prolongation of bargaining and war without additional assumptions about incomplete information or commitment problems. A better possible explanation might be that perhaps UN peacekeepers introduce incomplete information that would otherwise not be as relevant. During a war without peacekeepers the most important determinant of a faction's bargaining strength is its military strength and it could be argued that after several years of war relative military strength of the factions is fairly well known. ${ }^{25}$ Once UN peacekeepers intervene military strength may no longer be as salient to the outcome of negotiations because peacekeepers can reduce or eliminate the possibility that a faction will lose the war outright. Instead incomplete information about less observable characteristics like the discount rates of the factions' leadership become more important. Obviously this argument is speculative at this point but we think it is worthy of more formal inquiry.

A second question concerns the differences in bias in the two subsamples. We find that failing to control for the effects of nonrandom assignment produces an underestimate of the effect of UN peacekeeping in the post-war sample and an overestimate of the effect of UN peacekeeping in the in-war sample. One possible interpretation of this findings is that the United Nations is intervening in hard post-war cases and easy in-war cases. Why might this be? Why would the Security Council heroically enter hard cases in postwar settings while picking easy cases while wars are still ongoing? We think the most plausible explanation is doctrinal. We would argue that the United Nations knows the pitfalls of entering into ongoing wars described above. Furthermore, we would argue that it is aware that it is good at peacekeeping but not good at war fighting (Doyle and Sambanis 2006). Thus the Security Council may be steering away from spending scarce

24 We would add however that, if this is the process at work, then we should not necessarily interpret UN peacekeepers' inability to end ongoing wars as a failure (as Luttwak (1999) does) because the purpose of these missions may not be to shorten the war but instead to prevent a humanitarian disaster. If this is the case our dependent variable is not capturing the objectives of the Security Council in these in-war cases. Perhaps a better measure of UN success in such case may be casualty reduction.

25 This is the basis of Fearon's preference for commitment-based explanations for long wars. $\mathrm{He}$ argues that "... it strains credulity to imagine that the parties to a war that has been going on for many years, and that looks very much the same from year to year, can hold any significant private information about their capabilities or resolve." (Fearon 2004, p. 290) 
resources on missions to ongoing wars unless they know that those ongoing wars have a very good chance of ending soon or there is some other compelling reason such as a humanitarian disaster as was the case in Somalia or Bosnia. ${ }^{26}$

\section{CONCLUSION}

Do UN interventions cause peace in civil wars? In answering this question it is crucial to take into account the fact that UN missions are not randomly assigned to civil conflicts. Was UN intervention truly causing peace or was the peace due to other factors that either by chance or design characterized the conflicts into which the UN intervened? We have addressed the nonrandom assignment of UN missions using matching techniques. Our results suggest that the United Nations truly has had an important independent causal effect in prolonging periods of peace and that that effect is even larger than would be estimated had we not corrected for the effects of nonrandom assignment of UN missions. In our in-war sample we could find no causal effect from UN interventions in shortening the war. Controlling for the effects of nonrandom assignment was equally important for this result because our estimates when we did not correct for it indicated that UN operations were effective in helping countries transition out of war and into peace.

Previous quantitative empirical research that has argued that UN interventions foster peace has been questioned by recent methodological critiques because it was based on comparisons to extreme counterfactuals and therefore its conclusions are highly model dependent. Matching techniques have allowed us to address this issue and get more reliable estimates of the causal effect of UN interventions in civil wars.

Our aims in writing this paper have been twofold. We have sought to introduce to a wider audience a different method that avoids in a straightforward way the twin pitfalls of model dependence arising from the use of extreme counterfactuals and the need for an instrument when addressing the nonrandom selection problem. Second, by employing these methods, we have hoped to provide a more robust set of findings about the effectiveness of UN intervention. The implications of our findings for policy and the development of UN doctrine are clear. The UN is quite good at peacekeeping. It is not good at war fighting. Although this point has been raised by others, we reach this conclusion based on a more robust analysis of the causal effect (or lack thereof) of UN intervention and therefore we can have much more confidence in the conclusion.

26 Another possible reason for the apparent difference in bias is in the coding of the end dates of the wars. Coding war end dates is difficult and obviously a somewhat arbitrary task. In some of the cases it is possible that the war was effectively over but for whatever reason (perhaps a crucial peace treaty did not go into effect until later) the Armed Conflict Dataset, which we use, did not code the wars ending until later. There are a few cases in our ongoing-war sample where this may have occurred because the war end dates are within a few months of the start date for the UN mission. They are Georgia, Liberia, and El Salvador. Removing these three missions from our ongoing-war sample produced very similar estimates to those reported above although statistical significance was reduced. We think the categorization of wars described in the main text is the most defensible because it adheres to the carefully devised definitions of the Armed Conflict Dataset project. 


\section{APPENDIX}

In this section we describe our data in somewhat greater detail. Descriptive statistics are presented in Table A.1. QQPlots for the post-matched samples are shown in Figures A.1 and A.2.

Table A.1. Descriptive statistics

\begin{tabular}{|c|c|c|c|c|}
\hline Variable & Mean & Std. Dev. & Min & Max \\
\hline \multicolumn{5}{|l|}{ Post-Conflict Sample, $n=87$} \\
\hline UN intervention & 0.218 & 0.416 & 0 & 1 \\
\hline Log (Cumulative battle deaths) & 7.157 & 3.118 & 0 & 13.229 \\
\hline Duration of the last war & 56.885 & 79.803 & 1 & 360 \\
\hline Ethnic faractionalization & 54.911 & 25.490 & 0.498 & 90.163 \\
\hline Log population & 9.344 & 1.370 & 6.363 & 12.139 \\
\hline Log (Mountainous) & 2.347 & 1.387 & 0 & 4.421 \\
\hline Log (Military personnel) & 3.739 & 1.635 & 0.693 & 7.313 \\
\hline Log GDP per capita & 6.566 & 1.011 & 4.689 & 9.30 \\
\hline Polity 2 & -1.218 & 5.700 & -10 & 10 \\
\hline Eastern Europe & 0.195 & 0.399 & 0 & 1 \\
\hline Latin America & 0.138 & 0.347 & 0 & 1 \\
\hline Asia & 0.149 & 0.359 & 0 & 1 \\
\hline Sub-Saharan Africa & 0.402 & 0.493 & 0 & 1 \\
\hline North Africa/Middle East & 0.115 & 0.321 & 0 & 1 \\
\hline \multicolumn{5}{|l|}{ In-War Sample, $n=3999$} \\
\hline UN intervention & 0.136 & 0.343 & 0 & 1 \\
\hline Non-UN 3rd party intervention & 0.126 & 0.332 & 0 & 1 \\
\hline Log (Battle deaths) & 6.749 & 1.754 & 0 & 10.780 \\
\hline Coup/Revolution & 0.036 & 0.187 & 0 & 1 \\
\hline Sons-of-the-Soil & 0.387 & 0.487 & 0 & 1 \\
\hline Rebels contraband funded & 0.418 & 0.493 & 0 & 1 \\
\hline Ethnic fractionalization & 55.036 & 26.606 & 0.498 & 90.163 \\
\hline Log (Population) & 10.001 & 1.367 & 6.229 & 13.864 \\
\hline Log (Mountainous) & 2.793 & 1.243 & 0 & 4.407 \\
\hline Log (Military personnel) & 4.384 & 1.472 & 0 & 7.244 \\
\hline Eastern Europe & 0.068 & 0.251 & 0 & 1 \\
\hline Latin America & 0.125 & 0.331 & 0 & 1 \\
\hline Asia & 0.323 & 0.468 & 0 & 1 \\
\hline Sub-Saharan Africa & 0.378 & 0.485 & 0 & 1 \\
\hline North Africa/Middle East & 0.107 & 0.309 & 0 & 1 \\
\hline
\end{tabular}


Log Cumulative Battle Death

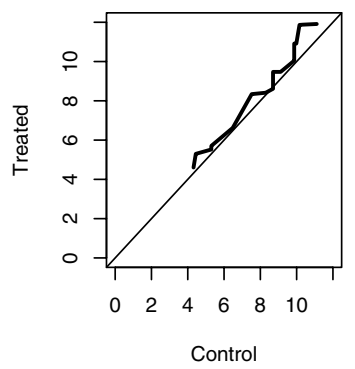

Log Population Size

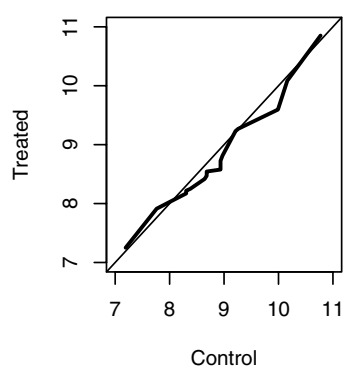

Duration of Last War

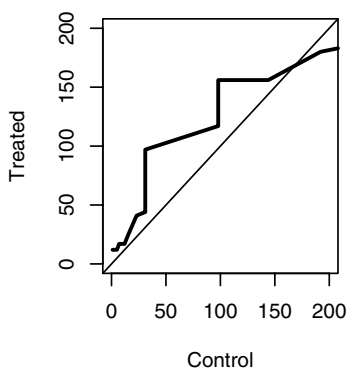

Log Mountainous

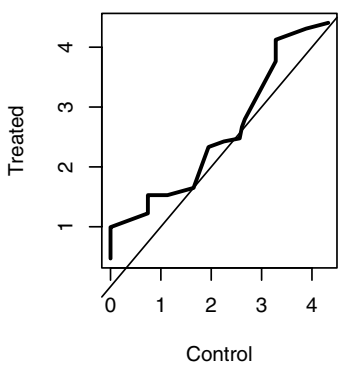

Ethnic Fractionalizaion

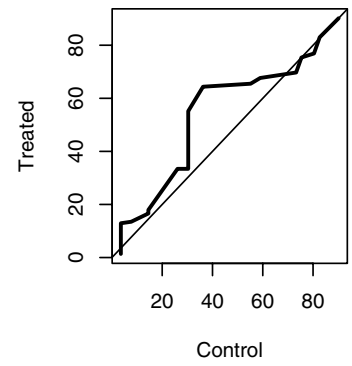

Log Military Personnel

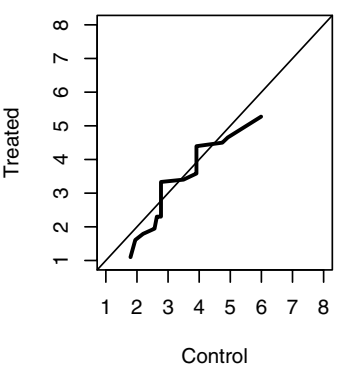

Log GDP per Capita

Polity
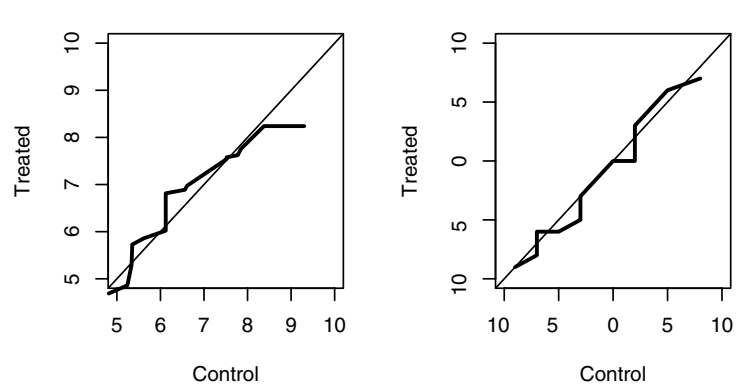

Figure A.1. QQ plots, post-conflict sample.

\section{Post-Conflict Sample}

As mentioned in the main text our dependent variable is the duration of a period of peace following a civil war. We focus on the post-Cold War period; therefore we restrict our attention to periods of peace following the end of a civil war that existed between January 1988 and December 2003. ${ }^{27}$ Our civil war data come from the Armed Conflict Dataset,

27 We are aware, of course, that, strictly speaking, the Cold War was still on in 1988, however the sea change in peacekeeping that occurred with the end of the Cold War really began in 1988. 


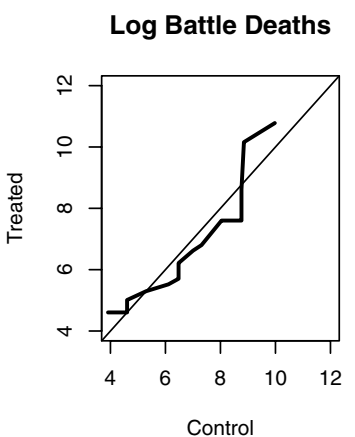

Log Population Size

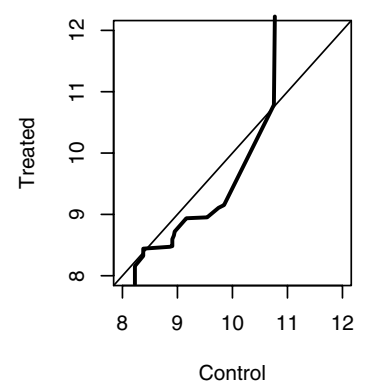

War Duration

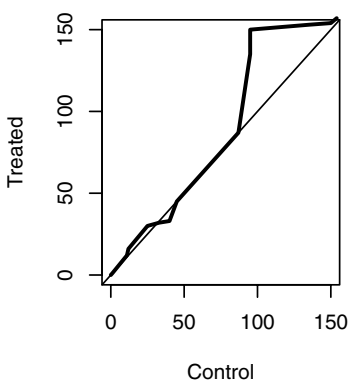

Log Mountainous

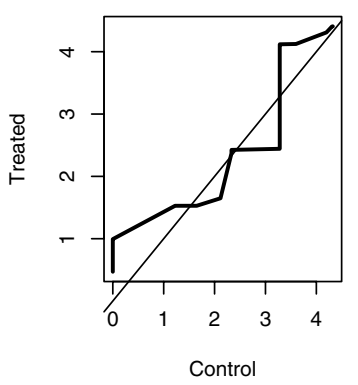

Ethnic Fractionalizaion

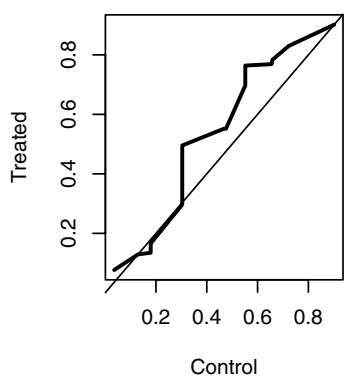

Log Military Personnel

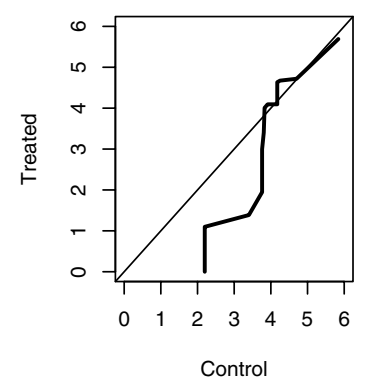

Figure A.2. QQ plots, in-war sample.

Version 3.0. We use all Type 3 (Internal) and Type 4 (Internationalized Internal) armed conflicts listed in the armedconflicts.xls sheet (Gleditsch et al. 2002). As end dates were not available from the Armed Conflict Dataset we augmented them with end dates from an earlier version of Gates and Strand (2006) which was kindly supplied by Kristian Gleditsch. In addition we have a full set of covariates only through December 2001 and so our sample excludes any peace periods that began after January 2002. A period of peace either ends when a civil war starts or is right censored at December 2003. In all, there were 87 such periods of which the United Nations intervened in 19.

We are using a country-level, not a war-level, measure of peace. We do not examine the length of peace after the end of a particular war; instead we examine the length of peace for an entire country. One complication is that some countries may experience several conflicts concurrently. These conflicts are often difficult to disentangle and are almost certainly not independent observations, which is why we have adopted the country-level approach for our dependent variable. However, it does come at a cost. The clearest example of this cost is for Indonesia. During the 1990's, the Armed Conflict Dataset identifies at least two intermittent conflicts, one in East Timor and another in Aceh. Whereas the conflict in East Timor ended in 1998, the one in Aceh started in 1999. Thus, our measure is unable to pick up the post-conflict period of peace in East Timor before 
it became an independent country in May 2002, because by our country-level measure Indonesia remained in a state of conflict due to the conflict in Aceh. We cannot therefore evaluate the role of the UN Peacekeeping mission in prolonging peace in East Timor. Fortunately, these cases are rare. The UN mission to East Timor is the only UN mission excluded due to this issue.

Data for our treatment variable come from the United Nations Peacekeeping web site. ${ }^{28}$ We examine all UN missions that address internal conflicts that ended in the period 1988 through 2002. Our sample excludes one on-going mission that was initiated before 1988, UNFICYP in Cyprus (initiated in 1964), because the post-conflict period began before January 1988, as well as any missions initiated after 2002, such as UNMIL in Liberia, UNMIS in Sudan or UNOB in Burundi. Table A.2 lists all such UN missions. From these data, we created an indicator variable equal to 1 if the United Nations was present at any point during a period of peace, and 0 otherwise. In other words a postconflict period either receives a UN treatment or it does not. We adopt this measure of the UN intervention because we wish to test if a UN intervention led to a lasting peace, that is peace even after $\mathrm{UN}$ troops left the country. Using a time-varying approach for UN intervention (that is coding UN intervention 1 only for the periods the United Nations was present) would only show if the UN intervention reduced the hazard rate of war while it was stationed in the country. Our measurement choice is not without its drawbacks however in that it essentially gives the UN intervention credit for the months of peace before it intervened in the country. Fortunately this is not a major problem in practice. If the United Nations intervenes at all it almost always does so in the first month of peace. Of the 19 post-conflict UN interventions, the United Nations was present within the first month for 16 of them.

Our UN mission variable is a country-level variable so it does not measure the effect of any particular UN mission, e.g., UNMIH present in Haiti from September 1993 to June 1996. Instead we examine the entire effect of a continuous United Nations' presence in a country during a particular period of peace, e.g., the total effect of the United Nations' presence in Haiti under various different acronyms (UNMIH, UNSMIH, UNTMIH and MIPONUH) from September 1993 to March 2000. Based on our definitions of our sample and our dependent variable, we exclude three UN peacekeeping presences initiated between 1988 and 2002 from our subsequent analysis, those in Macedonia, the Central African Republic and in East Timor. We exclude the first two cases because they were neither post-conflict nor in-war interventions. We exclude the East Timor mission, first, for the reason discussed above - based on our definition of our dependent variable Indonesia does not belong in the post-conflict sample — and, second, after East Timor's independence the conflict had to be excluded due to missing data.

\section{In-War Sample}

For the in-war sample the source of our dependent variable and treatment variable are the same as discussed in the previous section. As in the post-conflict sample our dependent

28 http://www.un.org/Depts/dpko/dpko/index.asp. 
Table A.2. UN missions in internal conflicts 1988-2002

\begin{tabular}{|c|c|c|c|c|c|}
\hline Country & Mission & Start date & End date & $\begin{array}{l}\text { Post-conflict } \\
\text { sample }\end{array}$ & $\begin{array}{l}\text { In-war } \\
\text { sample }\end{array}$ \\
\hline Lebanon & UNIFIL & Mar-78 & - & 1 & 1 \\
\hline \multirow[t]{4}{*}{ Angola } & UNAVEMI & Dec-88 & Jun-91 & & \\
\hline & UNAVEMII & Jun-91 & Feb-95 & & \\
\hline & UNAVEMIII & Feb-95 & Jun-97 & & \\
\hline & MONUA & Jun-97 & Feb-99 & & 1 \\
\hline Namibia & UNTAG & Apr-89 & Mar-90 & 1 & \\
\hline $\begin{array}{l}\text { Central America } \\
\text { (Nicaragua) }\end{array}$ & ONUCA & Nov-89 & Jan-92 & 1 & \\
\hline $\begin{array}{l}\text { Western Sahara } \\
\text { (Morocco) }\end{array}$ & MINURSO & Apr-91 & - & 1 & \\
\hline El Salvador & ONUSAL & Jul-91 & Apr-95 & 1 & 1 \\
\hline \multirow[t]{2}{*}{ Cambodia } & UNAMIC & Oct-91 & Mar-92 & & \\
\hline & UNTAC & Mar-92 & Sep-93 & & 1 \\
\hline \multirow[t]{4}{*}{ Croatia } & UNPROFOR & Feb-92 & Mar-95 & 1 & 1 \\
\hline & UNCRO & Mar-95 & Jan-96 & & 1 \\
\hline & UNTAES & Jan-96 & Dec-97 & & \\
\hline & UNPSG & Jan-98 & Oct-98 & 1 & \\
\hline \multirow[t]{2}{*}{ Somalia } & UNOSOMI & Apr-92 & Mar-93 & & \\
\hline & UNOSOMII & Mar-93 & Mar-95 & & 1 \\
\hline Mozambique & ONUMOZ & Dec-92 & Dec-94 & 1 & \\
\hline Georgia & UNOMIG & Aug-93 & - & 1 & 1 \\
\hline \multirow[t]{2}{*}{ Bosnia/Herzegovina } & UNPROFOR & Jun-92 & Mar-95 & & 1 \\
\hline & UNMIBH & Dec-95 & Dec-02 & 1 & \\
\hline Liberia & UNOMIL & Sep-93 & Sep-97 & 1 & 1 \\
\hline \multirow[t]{4}{*}{ Haiti } & UNMIH & Sep-93 & Jun-96 & & \\
\hline & UNSMIH & Jun-96 & Jul-97 & & \\
\hline & UNTMIH & Aug-97 & Nov-97 & & \\
\hline & MIPONUH & Dec-97 & Mar-00 & 1 & \\
\hline \multirow[t]{2}{*}{ Rwanda } & UNOMUR & Jun-93 & Sep-94 & & \\
\hline & UNAMIR & Oct-93 & Mar-96 & 1 & 1 \\
\hline Tajikistan & UNMOT & Dec-94 & May-00 & 2 & 2 \\
\hline Guatemala & MINUGUA & Jan-97 & May-97 & 1 & \\
\hline \multirow[t]{2}{*}{ Sierra Leone } & UNOMSIL & Jul-98 & Oct-99 & & \\
\hline & UNAMSIL & Oct-99 & Dec-05 & 1 & 1 \\
\hline
\end{tabular}


Table A.2. (Continued)

\begin{tabular}{|c|c|c|c|c|c|}
\hline Country & Mission & Start date & End date & $\begin{array}{l}\text { Post-conflict } \\
\text { sample }\end{array}$ & $\begin{array}{l}\text { In-war } \\
\text { sample }\end{array}$ \\
\hline Yugoslavia (Kosovo) & UNMIK & Jun-99 & - & 1 & \\
\hline Indonesia (East Timor) & UNTAET & Oct-99 & May-02 & & 1 \\
\hline D.R. of the Congo & MONUC & Dec-99 & - & 1 & 1 \\
\hline Total: & & & & 19 & 16 \\
\hline
\end{tabular}

Note: UNFICYP is excluded because the war in Cyprus ended well before our sample period. MINURCA in the Central African Republic and UNPREDEP in Macedonia are excluded because there was no war in those countries prior to or during the United Nations involvement. UNMISET in East Timor is excluded because of missing data. Tajikistan transitioned out and then back into war during the UN mission according to the PRIO/Uppsala data set which accounts for the two post-conflict and in-war periods recorded in the table.

variable is right censored at December 2003, as this is the last date for which we have data on civil wars. In addition, we also include several variables coded by Fearon (2004). Fearon's data set ends in 1999 and is missing several wars that are in the Armed Conflict Dataset because Fearon uses a higher battle deaths threshold for a conflict to qualify as a war. Therefore, we were forced to exclude some wars: all those that began after December 1999 and all those ongoing wars before December 1999 that were not in Fearon's dataset.

As a robustness check we also estimated our model excluding the variables that we obtained from Fearon's data set and found that our results are substantively equivalent using the larger sample that resulted from excluding those variables. We are most convinced by the results we present in this paper, however, because they control for confounding factors that Fearon found to be important, notably the availability of contraband to fund the rebel movement. Hence, we examine all conflicts that were identified by both the Armed Conflict Data set and Fearon (2004) and that were either on-going as of January 1988 or were initiated between January 1988 and December 1999. A period of war ends either when the country is no longer characterized by any civil conflict according to Fearon's data set or is right-censored in December 2003, the point at which the Armed Conflict Data set ends. In all, there were 69 such periods. The United Nations was present in 16 of them. As in the previous section we could not include UN missions begun after December 2002 because of data limitations of other covariates.

\section{REFERENCES}

Adekeye A. 2002. Building Peace in West Africa: Liberia, Sierra Leone, and Guinea-Bissau. Lynne Rienner Publisher.

Andersson A. 2000. "Democracy and UN Peacekeeping Operations." International Peacekeeping 7: $1-22$. 
Balch-Lindsay D., and A. Enterline. 2000. "Killing Time: The World Politics of Civil War Duration, 1820 - 1992." International Studies Quarterly 44: 615-652.

Burma 'terrorising ethnic minorities'. 2002. BBC Nems Online, Retrieved 3 April 2008 from http:// news.bbc.co.uk/2/hi/asia-pacific/2132986.stm.

Burmese rebel leader is shot dead. 2008. BBC Nems Online. Retrieved 4 April 2008 from http:// news.bbc.co.uk/2/hi/asia-pacific/7244684.stm.

Clarke W., and J. Herbst. 1997. "Somalia and the Future of Humanitarian Intervention." In Learning from Somalia, eds. Walter Clarke and Jeffrey Herbst, Westview, pp. 3-19.

Collier P., and A. Hoeffler. 1998. "On the Economic Causes of Civil War." Oxford Economic Papers 50: $563-573$.

Collier P., and A. Hoeffler. 2004. "Greed and Grievance in Civil War." Oxford Economic Papers 56: $563-596$.

Dallaire R. 2003. Shake Hands with the Devil: The Failure of Humanity in Rmanda. Random House.

David, S. J., S. Bremer, and J. Stuckey. 1972. "Capability Distribution, Uncertainty, and Major Power War, 1820-1965." In Peace, War and Numbers, ed. Bruce Russett, SAGE, pp. 19-48.

De Jonge Oudratt, C. 1996. "The United Nations and Internal Conflict." In International Dimensions of Internal Conflicts, ed. M. E. Brown, MIT Press, chapter 15, pp. 489-535.

Doyle, M., and N. Sambanis. 2000. "International Peacebuilding: A Theoretical and Quantitative Analysis." American Political Science Reviem 94: 779-802.

Doyle, M. W., and N. Sambanis. 2006. Making War and Building Peace. Princeton University Press.

Doyle, M. W., and N. Sambanis. 2007. "No Easy Choices: Estimating the Effects of United Nations Peacekeeping (Response to King and Zeng)." International Studies Quarterly 51: 217-226.

Elbadawi, I., and N. Sambanis. 2002. "How Much War Will We See?” Fournal of Conflict Resolution, 46: $307-334$.

Fearon, J. 1995. “Rationalist Explanations for War.” International Organization 49: 379-414.

Fearon, J. D. "Why do Some Civil Wars Last Longer than Others?" Fournal of Peace Research 41: $275-301$.

Fearon, J. D., and D. Laitin. 2003. "Ethnicity, Insurgency and Civil War." American Political Science Reviem 97: 75-90.

Fortna, V. P. 2004. "Does Peacekeeping Keep Peace? International Intervention and the Duration of Peace After Civil War." International Studies Quarterly 48: 269-292.

Fortna, V. P. 2008. Peacekeeping and the Peacekept Maintaining Peace after Civil War. Princeton University Press.

Gates, S., and H. Strand. 2006. "Modeling the Duration of Civil Wars: Measurement and Estimation Issues." Retrieved 4 April 2008 from http://www.prio.no/CSCW/Datasets/ArmedConflict/Onset-and-Duration-of-Intrastate-Conflict/Duration-Data-v1-2006b/.

Gilligan, M., and S. J. Stedman. 2003. "Where Do the Peacekeepers Go?" International Studies Reviem 5: $37-54$.

Gleditsch, N. P., P. Wallensteen, M. Eriksson, M. Sollenberg and H. Strand. 2002. "Armed Conflict: 1946-2001.” Fournal of Peace Research 39: 615-637.

Hartzell, C., M. Hoddie and D. Rothchild. 2001. "Stabilizing the Peace After Civil War.” International Organization 55: 183-208.

Hegre, H. 2004. "The Duration and Termination of Civil War." Fournal of Peace Research 41: 243-252.

Hegre, H., and N. Sambanis. 2006. "Sensitivity Analysis of Empirical Results on Civil War Onset." Fournal of Conflict Resolution 50: 508-535.

Ho, D., K. Imai, G. King and E. A. Stuart. 2007. "Matching as Nonparametric Preprocessing for Reducing Model Dependence in Parametreic Causal Inference." Political Analysis 15: 199-236.

Howe, T. J. 1995. "The United States and the United Nations in Somalia: The Limits of Involvement." Washington Quarterly 18: 47.

Imai, K., G. King and E. A. Stuart. 2006. "The Balance Test Fallacy in Matching Methods for Causal Inference.” Available at http://gking.harvard.edu/projects/cause.shtml.

Indonesia flashpoints: Papua. 2004. BBC Nems Online. Retrieved 4 April 2008 from http://news.bbc. co.uk/2/hi/asia-pacific/3815909.stm.

Indonesia flashpoints: Aceh. 2005. BBC Nems Online. Retrieved 4 April 2008 from http://news.bbc. co.uk/2/hi/asia-pacific/3809079.stm.

Jett, D. C. 2001. Why Peacekeeping Fails. Palgrave. 
Jones, B. D. 2001. Peacemaking in Rmanda: The Dynamics of Failure. Lynne Reiner.

King, G., and L. Zeng. 2006. "The Dangers of Extreme Counterfactuals.” Political Analysis 14: 131-159.

King, G., and L. Zeng. 2007. "When Can History Be Our Guide? The Pitfalls of Counterfactual Inference." International Studies Quarterly 51: 183-210.

Lacina, B., and N. P. Gleditsch. 2005. "Monitoring Trends in Global Combat: A New Dataset of Battle Deaths." European Fournal of Population 21: 145-166.

Luttwak, E. N. 1999. “Give War a Chance.” Foreign Affairs 78: 36-44.

Massey, S. 2006. "Multiparty Mediation in the Guinea-Bissau Civil War." In Ending Africa's Civil Wars: Progressing to Peace, eds. O. Furley and R. May, Ashgate, chapter 6, pp. 83-98.

McClintock, C. 1998. Revolutionary Movements in Latin America: El Salvador's FMLN and Peru's Shining Path. United States Institute of Peace.

Miguel. E., S. Satyanath and E. Sergenti. 2004. "Economic Shocks and Civil Conflict: An Instrumental Variables Approach." Fournal of Political Economy 112: 725-753.

Morrow, J. D. 2007. "Officers King and Zeng and the Case of the Unsupported Counterfactual." International Studies Quarterly, 51: 227-229.

Mullenbach, M. J. 2005. "Deciding to Keep the Peace: Analysis of International Influences on the Establishment of Third-Party Peacekeeping Missions.” International Studies Quarterly 49: 529-555.

Pearl, J. 2001. Causality: Models, Reasoning, and Inference. Cornell University Press.

Powell, R. 2004. "The Inefficient Use of Power: Costly Conflict with Complete Information." American Political Science Reviem 98: 231-241.

Powell, R. 2006. "War as a Commitment Problem.” International Organization 60: 169-203.

Przeworski, A., and H. Teune. 1970. The Logic of Comparative Social Inquiry. Wiley.

Regan, P. M. 2002. "Third Party Interventions and the Duration of Intrastate Conflicts." fournal of Conflict Resolution, 46: 55-73.

Rosenbaum, P. R. 2002. Observational Studies. Springer.

Rosenbaum, P. R., and D. B. Rubin. 1984. "Reducing Bias in Observational Studies using Subclassification on the Propensity Score." Journal of the American Statistical Association 79: 516-524.

Rubin, D. B. "Using Multivariate Matched Sampling and Regression Adjustment to Control Bias in Observational Studies." Fournal of the American Statistical Association 74: 318-328.

Schrodt, P. A. 2007. "Of Dinosaurs and Barbecue Sauce: A Comment on King and Zeng." International Studies Quarterly 51: 211-215.

Sekhon, J. S. 2006a. "Alternative Balance Metrics for Bias Reduction in Matchcing Methods for Causal Inference." Available at http://sekhon.berkeley.edu/matching.

Sekhon, J. S. 2006b. "Matching: Algorithms and Software for Multivariate and Propensity Score Matching with Balance Optimization via Genetic Search. Available at http://sekhon. berkeley.edu/matching.

Sekhon, J. S. Forthcoming. "Multivariate and Propensity Score Matching Software with Automated Balance Optimization: The Matching Package for R.” Fournal of Statistical Software.

Sekhon J. S., and W. R. Mebane. 1998. "Genetic Optimization using Derivatives." Political Analysis 7: $187-210$.

Singer, J. D. 1987. "Reconstructing the Correlates of War Dataset on Material Capabilities of States, 1816-1985." International Interactions 14: 115-132.

Smith, J., and A. Stam. 2003. "Mediation and Peacekeeping in a Random Walk Model of Civil and Interstate War." International Studies Reviem 5: 115-135.

Timeline: East Timor. 2008. BBC News Online. Retrieved 4 April 2008 from http://news.bbc.co.uk/ 2/hi/asia-pacific/country_profiles/1504243.stm.

Timeline: Guinea-Bissau. 2008. BBC Nems Online. Retrieved 31 March 2008 from http://news.bbc.co.uk/2/hi/africa/country_profiles/1043376.stm.

Timeline: Indonesia. 2008. BBC Nems Online. Retrieved 4 April 2008 from http://news.bbc.co.uk/ 2/hi/asia-pacific/country_profiles/1260546.stm.

Timeline: Liberia. 2008. BBC News Online. Retrieved 31 March 2008 from http://news.bbc.co.uk/ 2/hi/africa/country_profiles/1043567.stm.

Walter, B. F. 1997. "The Critical Barrier to Civil War Settlement.” International Organization 51: $335-364$.

Werner, S., and A. Yuen. 2005. “Making and Keeping Peace." International Organization 59: 261-292. 